\title{
Adam Przybylowski*
}

Akademia Morska w Gdyni

\section{WSPÓŁCZESNA MOBILNOŚĆ - PREFERENCJE PASAŻERÓW PORTU LOTNICZEGO W GDAŃSKU}

\begin{abstract}
Streszczenie
Współczesne aglomeracje jako silne ośrodki gospodarcze są najczęściej punktami, w których krzyżują się ważne szlaki transportowe, w tym lotnicze. Pasażerski transport lotniczy jest jednym z najszybciej rozwijających się segmentów rynku transportowego. Dlatego też zasadne jest prowadzenie badań w celu monitorowania preferencji pasażerów, aby monitorować potrzeby związane z rosnącą mobilnością. Celem publikacji jest przedstawienie wybranych zagadnień dotyczących współczesnej mobilności na przykładzie preferencji pasażerów portu lotniczego w Gdańsku. Do zrealizowania celu pracy została zastosowana metoda badania zbiorowości incydentalnej poprzez ankietę $\mathrm{w}$ formie wywiadu, za pomocą kwestionariusza ankiety. Pozytywnie zweryfikowano hipotezę zakładającą, iż dla pasażerów największe znaczenie ma cena oferty, ale jednocześnie wpływ na ich decyzje mają inne czynniki, m.in. odległość od lotniska.
\end{abstract}

Słowa kluczowe: mobilność, pasażerowie, port lotniczy Gdańsk

\footnotetext{
* Adres e-mail: a.przybylowski@wpit.am.gdynia.pl.
} 


\section{Wprowadzenie}

Współczesne aglomeracje doświadczają wielu problemów związanych z organizacją przemieszczeń ludności. Wynika to z dużego skomplikowania ich systemów transportowych, które charakteryzują się mnogością przewoźników, organizatorów i form transportu. Także transport międzyregionalny i krajowy rozwijają się w bardzo szybkim tempie, a aglomeracje miejskie jako silne ośrodki gospodarcze są najczęściej punktami, w których krzyżują się ważne szlaki transportowe, w tym lotnicze. Transport lotniczy, zwłaszcza pasażerski, jest jednym z najszybciej rozwijających się segmentów rynku transportowego. Analitycy prognozują, że do 2033 roku będzie on rósł o około 5\% rocznie. Dlatego też zasadne jest prowadzenie badań w celu monitorowania preferencji pasażerów, aby wychodzić naprzeciw potrzebom związanym z rosnącą mobilnością. Celem artykułu jest przedstawienie wybranych zagadnień dotyczących współczesnej mobilności na przykładzie preferencji pasażerów portu lotniczego w Gdańsku. Zastosowano metodę badania zbiorowości incydentalnej poprzez ankietę w formie wywiadu, za pomocą kwestionariusza ankiety. Sformułowano hipotezę, iż dla pasażerów największe znaczenie ma cena oferty, ale jednocześnie wpływ na ich decyzje mają inne czynniki, między innymi odległość od lotniska.

\section{Mobilność a lokalizacja portów lotniczych}

Pomiędzy aglomeracyjnymi systemami transportowymi a ich otoczeniem, ze względu na duże natężenie różnych rodzajów ruchu na stosunkowo niewielkich obszarach, pojawia się szereg oddziaływań o charakterze pozytywnym lub negatywnym (Banister, 2011, s. 1538-1546). Rodrigue i inni proponują, by pojęcie transportu definiować jako system, który obejmuje ogół relacji pomiędzy jego składowymi, czyli siecią, węzłami oraz potrzebami przewozowymi. Według nich na sieć składa się infrastruktura transportowa, która umożliwia przemieszczenia w określonych kierunkach (Rodrigue, Comtois, Slack, 2006, s. 138). Węzły to miejsca, gdzie podróże zaczynają się, kończą lub następuje transfer (przesiadka, przeładunek). Ostatni z elementów - potrzeby przewozowe - rozumie się jako popyt na przemieszczenia ludzi, towarów oraz informacji. Są one pochodną różnorodnych aktywności społeczno-gospodarczych na danym obszarze (Gadziński, 2013, s. 23). Najważniej- 
szymi czynnikami pozwalającymi ocenić system transportowy jest infrastruktura liniowa i punktowa transportu oraz oferta usługowa w zakresie jakości, częstotliwości, rytmiczności, położenia punktów transportowych i ceny. W tym aspekcie właściwy poziom dostępności ma zasadniczy wpływ na jakość życia obywateli oraz prawidłowe funkcjonowanie gospodarcze regionów, w tym miast (Litman, 2006). $\mathrm{Z}$ istoty mobilności wynika to, że ma ona wymiar fizyczny i może być opisana poprzez szereg czynników, które ją ułatwiają bądź utrudniają (Szołtysek, Otręba, 2015).

Litman zauważył, że wszystkie analizy dotyczące dostępności w transporcie powinny być analizowane od drzwi - do drzwi (ang. door-to-door), czyli od miejsca startu do miejsca przeznaczenia (Litman, 2006). Dostępność można mierzyć nie tylko czasem podróży, ale również za pomocą innych elementów decydujących o łatwości podróżowania (koszty, łatwość przesiadki, bliskość przystanku). Dystans podróży powinien być mierzony w odniesieniu do istniejącej sieci połączeń (a nie za pomocą linii prostej łączącej punkt początkowy i końcowy). W końcu w analizach dostępności ekonomicznej należy uwzględniać nie tylko koszty jednostkowego przejazdu, ale także koszty dodatkowe wynikające na przykład z opłat za parkowanie, konieczności napraw i przeglądów pojazdu itd. (głównie dla transportu indywidualnego).

Urbaniści pracujący nad planowaniem przestrzennym są zdania, że porty lotnicze powinny być zlokalizowane w pobliżu szeroko rozumianej aglomeracji oraz zintegrowane z nią. Główną zasadą powinno być stworzenie bezpiecznych stref do startu i lądowania, a jednocześnie miejsca te nie powinny znajdować się nad terenami zurbanizowanymi. Ważnym elementem przy planowaniu jest również poziom hałasu lotniczego, który można rozwiązać przy współudziale władz miasta i portu lotniczego, aby nie stwarzać dyskomfortu osobom mieszkającym w obrębie lotniska (Huderek-Glapska, 2011, s. 38). Należy zatem właściwie zagospodarować strefy wokół lotniska oraz zapewnić połączenia transportowe. Pasażer, wybierając pożądany kierunek, kieruje się subiektywnymi odczuciami i preferencjami, a przewoźnicy, chcąc zdobyć klienta, otwierają nowe destynacje, wyznaczają dogodniejsze godziny lotów oraz konkurencyjne ceny. Ważnym aspektem jest również dojazd do portów lotniczych oraz zadowolenie z systemu airports links. Przyjmuje się, że czas przejazdu do portu lotniczego powinien wynosić 15 minut dla portu o charakterze 
lokalnym, 25-30 minut o charakterze kontynentalnym oraz 30-50 minut dla portu o zasięgu transkontynentalnym (Barski, Fabirkiewicz, Jarosz, 2009).

Port lotniczy łączy ze sobą zazwyczaj kilka gałęzi transportu (Tłoczyński, 2016, s. 35). Wyróżnia się cztery poziomy integracji portu lotniczego z siecią transportową:

- poziom najwyższy - port lotniczy zintegrowany jest $\mathrm{z}$ węzłem autostrad, a na jego terenie zlokalizowany jest dworzec szybkiej kolei, np. Paryż Charles de Gaulle,

- port lotniczy zintegrowany jest z siecią kolejową na szczeblu regionalnym oraz z siecią dróg szybkiego ruchu (np. Londyn Heathrow),

- port lotniczy połączony jest z drogami szybkiego ruchu i posiada lokalne połączenie kolejowe z obsługiwanym miastem (np. Kraków Balice),

- port lotniczy posiada połączenie drogowe niebędące drogą szybkiego ruchu (np. Katowice).

Integracja portu lotniczego $\mathrm{z}$ transportem naziemnym jest o tyle istotna, że zwiększa dostępność portu lotniczego i umożliwia większej liczbie mieszkańców regionu korzystanie z usług portu i przewoźników lotniczych. Dodatkowo ścisła integracja portu z systemem dróg szybkiego ruchu i z transportem kolejowym ma znaczenie dla rozwoju przewozów towarowych (Bryx, 2014). Dostępność portu lotniczego jest szczególnie istotna dla wykorzystania jego potencjału, a tym samym generowania dodatkowych korzyści dla gospodarki regionu czy też miasta (Graham, 2008, s. 2).

Kluczowym terminem, który pozwala określić potencjał lotniska, jest tzw. strefa nacisku lotniska. Strefa ta to obszar, na którym prawdopodobieństwo wyboru danego lotniska jest tak wysokie, że większość osób decyduje się na podróż z niego. Jest to więc liczba osób mieszkająca w konkretnym obrębie wyznaczanym przez powszechnie akceptowany czas dojazdu do lotniska. Jej rozmiar zależy od systemu komunikacji drogowej i kolejowej w regionie, kondycji ekonomicznej regionu, jego struktury demograficznej i społecznej. Istotnymi czynnikami są również: siatka połączeń oferowana z danego lotniska, efektywność rozwiązań intermodalnych, konkurencja pomiędzy lotniskami, konkurencja pomiędzy poszczególnymi rodzajami transportu, bariery geograficzne i prawne, aktywność turystyczna regionu, parametry makroekonomiczne.

Według analiz Urzędu Lotnictwa Cywilnego, lata 2010-2030 będzie charakteryzował dość duży wzrost na rynku pasażerskim w Polsce, średnio 5,1\%. Oznacza to, 
że w roku 2030 przewozy osiągną poziom 59127000 osób. W porównaniu z rokiem 2013 to wzrost o 250\% (Ruciński, Madej, 2016) (rys. 1).

Rysunek 1. Przepustowość portów lotniczych w Polsce w latach 2013-2030

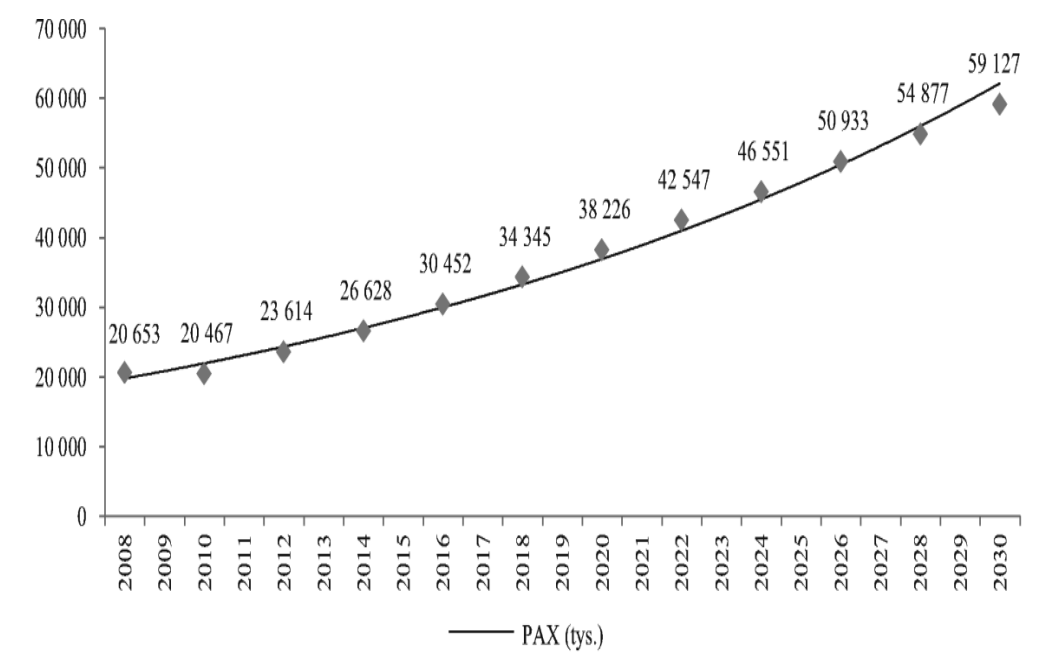

Źródło: http://www.ulc.gov.pl/pl/regulacja-rynku/3733-przepustowosc-portow-lotniczych/ (18.12.2016).

Na wzrost liczby pasażerów wpływ miały trzy podstawowe czynniki, w tym dwa związane są z akcesją Polski do UE:

- zniesienie barier podróżowania; do wszystkich krajów wspólnoty zaczął obowiązywać ruch bezwizowy,

- liberalizacja rynku lotniczego; umowy przestały być zawierane z udziałem instytucji państwowych, a przewoźnicy kreują połączenia w bezpośredniej współpracy z portami lotniczymi.

Trzecim czynnikiem jest pojawienie się tzw. tanich linii lotniczych, które kosztem komfortu pasażerów (w tym warunków dotarcia na lotnisko) i zakresu usług oferowanych w cenie biletu obniżyły ceny przelotów i tym samym zyskały konkurencyjność oraz nową grupę klientów, zorientowaną na niskie koszty podróży. 


\section{Preferencje pasażerów portu lotniczego w Gdańsku w świetle badań ankietowych}

Port Lotniczy im. L. Wałęsy w Gdańsku uznać można za przykład mieszanego modelu biznesowego lotniska - jako lotnisko będące docelowym miejscem podróży, a także bazą przewoźników niskokosztowych (Chakuu, Kozlowski, Nędza, s. 124). Jednocześnie ma ono charakter lotniska regionalnego. Lotniska tego typu są obiektami relatywnie mniejszymi od dużych lotnisk koncentrujących ruch pasażerski najważniejszej linii lotniczej i posiadających połączenia międzykontynentalne (huby), tak pod względem rozmiarów infrastruktury, jak i pod względem przepustowości i liczby obsługiwanych pasażerów.

Lotniska regionalne wykorzystują potencjał strefy nacisku i dlatego są miejscem rozpoczęcia podróży bądź miejscem docelowym dla podróżnych. Tradycyjnie lotniska takie odgrywają rolę destynacji, z których regionalni przewoźnicy zasilają pasażerami porty przesiadkowe (huby). W erze przewoźników niskokosztowych lotniska regionalne stały się kluczowymi elementami rozwoju przewozów lotniczych z punktu do punktu generowanego przez tego typu przewoźników (Burnewicz, 2011).

Dla gdańskiego lotniska strefa nacisku obejmuje obszar zamieszkały przez ok. 2 mln osób. Port lotniczy w Gdańsku nie ma poważnej konkurencji w północnej Polsce - najbliższe duże porty to lotniska w Modlinie i Poznaniu. W związku z tym waga tego portu lotniczego jest znacząca. Efektem tej sytuacji jest odsetek pasażerów z województw ościennych, który wynosi około 30\%. W 2016 roku Port Lotniczy Gdańsk im. Lecha Wałęsy obsłużył 4010864 pasażerów, co oznacza wzrost na poziomie $8 \% \mathrm{w}$ stosunku do roku 2015 i tym samym jest pierwszym rokiem w historii gdańskiego lotniska, w którym przekroczona została liczba 4 mln obsłużonych pasażerów (rys. 2) (www.airport.gdansk.pl, 2017).

Poniżej przedstawiono wybrane wyniki przeprowadzonych pilotażowych badań wśród 200 respondentów (98 kobiet i 102 mężczyzn) za pomocą ankiety bezpośredniej na terminalu gdańskiego lotniska w dniach 7-9 kwietnia 2017 roku (Wachnicka, 2017, s. 65). Największy odsetek respondentów (53\%) to osoby w wieku 26-35 lat. Drugą co do liczebności była grupa osób w wieku do 25 lat. Kolejne kategorie wiekowe to 36-45 oraz 46 plus odpowiednio $10 \%$ i 7\%. Najwięcej ankietowanych (38\%) to osoby, które podróżują raz na pół roku lub częściej. Nieco mniej, 23\%, 
korzysta z usług linii lotniczych rzadziej niż raz na pół roku, a tylko o dwa procent mniej podróżuje raz na trzy miesiące lub częściej. Jedynie $18 \%$ respondentów odpowiedziało, że lata raz w miesiącu lub częściej. Niespełna 47\% respondentów zaznaczyło cel wycieczkowy, odpowiednio $21 \%$ i $22 \%$ to cel zarobkowy i prywatny, natomiast $10,5 \%$ wskazało inny powód. Widoczny jest spadek zainteresowania destynacjami czysto zarobkowymi, które jeszcze kilka lat temu były dominujące.

Rysunek 2. Liczba pasażerów w porcie lotniczym w Gdańsku

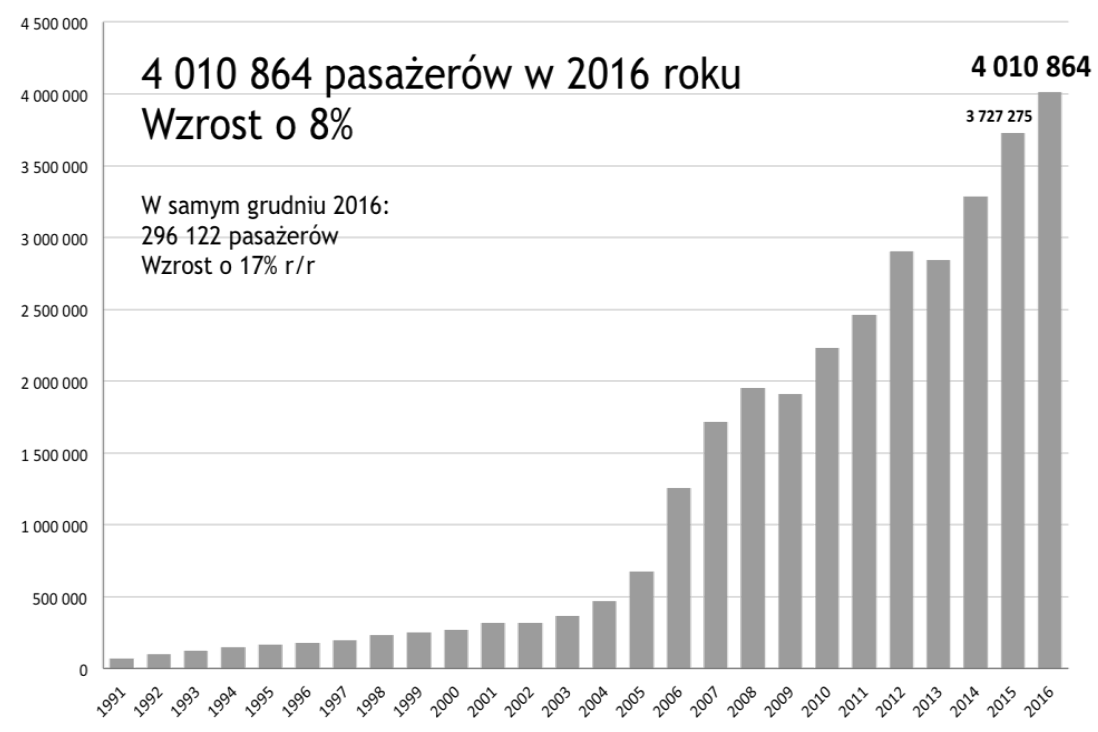

Źródło: http://www.airport.gdansk.pl/airport/news/news_1877_4-miliony-pasazerow-2016-roku.html (5.05.2017).

Respondenci w pytaniu dotyczącym odległości, jaką muszą pokonać, aby dotrzeć na lotnisko (rys. 3), odpowiadali następująco: niespełna 40\% dzieli od lotniska ponad 20 kilometrów, 33\% ok. 10-20 kilometrów, 16\% wskazało 5-10 kilometrów, a $12 \%$ niespełna 5 kilometrów. 
Rysunek 3. Odległość respondentów od lotniska

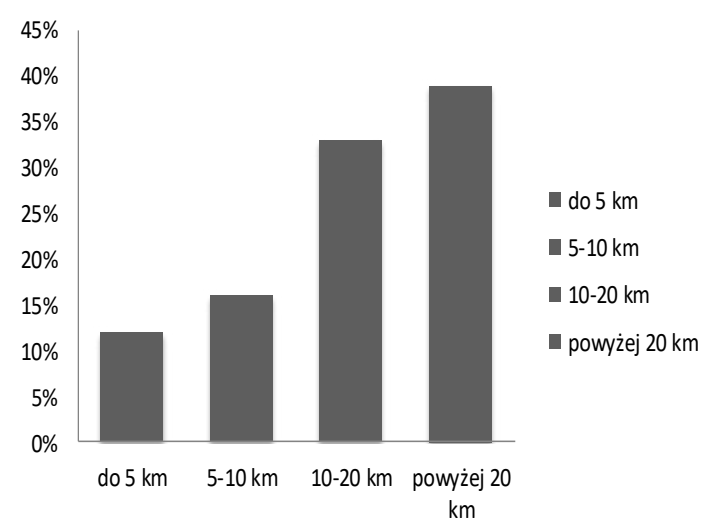

Źródło: opracowanie własne na podstawie: Wachnicka (2017), s. 76.

Najczęściej wskazywanym przez ankietowanych środkiem transportu dojazdu na lotnisko jest samochód osobowy (61\%). Znacznie mniej popularnym sposobem są dojazdy autobusem i koleją (18\% i 19\%) - te ostatnie dzięki nowoczesnej Pomorskiej Kolei Metropolitarnej (rys. 4).

Rysunek 4. Sposób dojazdu respondentów na lotnisko

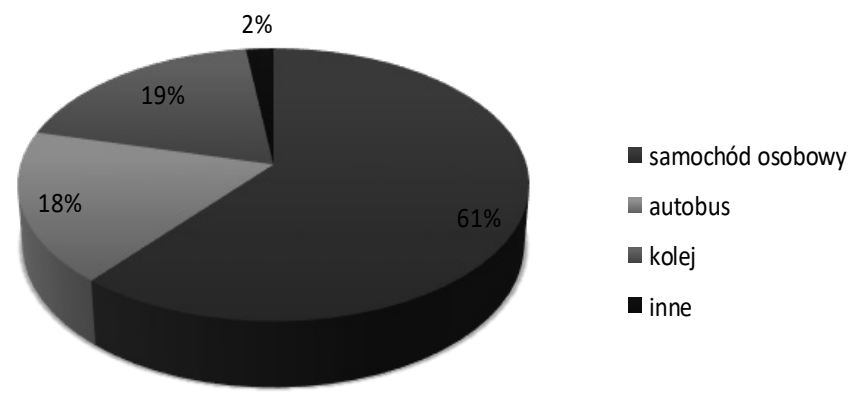

Źródło: opracowanie własne na podstawie: Wachnicka (2017), s. 78. 
W badaniu preferencji klientów można zauważyć, iż czynnikiem decydującym o wyborze oferty jest zdecydowanie cena biletu (69\% respondentów). Innymi czynnikami mającymi wpływ na decyzję respondentów są odpowiednio: akceptowalny rozmiar bagażu oraz odległość od lotniska, które za najważniejsze uznało 29 i 27\% badanych. Mniejszy odsetek respondentów za istotne uznał usługi dodatkowe, takie jak zakupy i posiłki - było to jedynie $9 \%$ respondentów, co przedstawia rysunek 5 .

Rysunek 5. Preferencje badanych respondentów odnośnie do oferty przewozowej

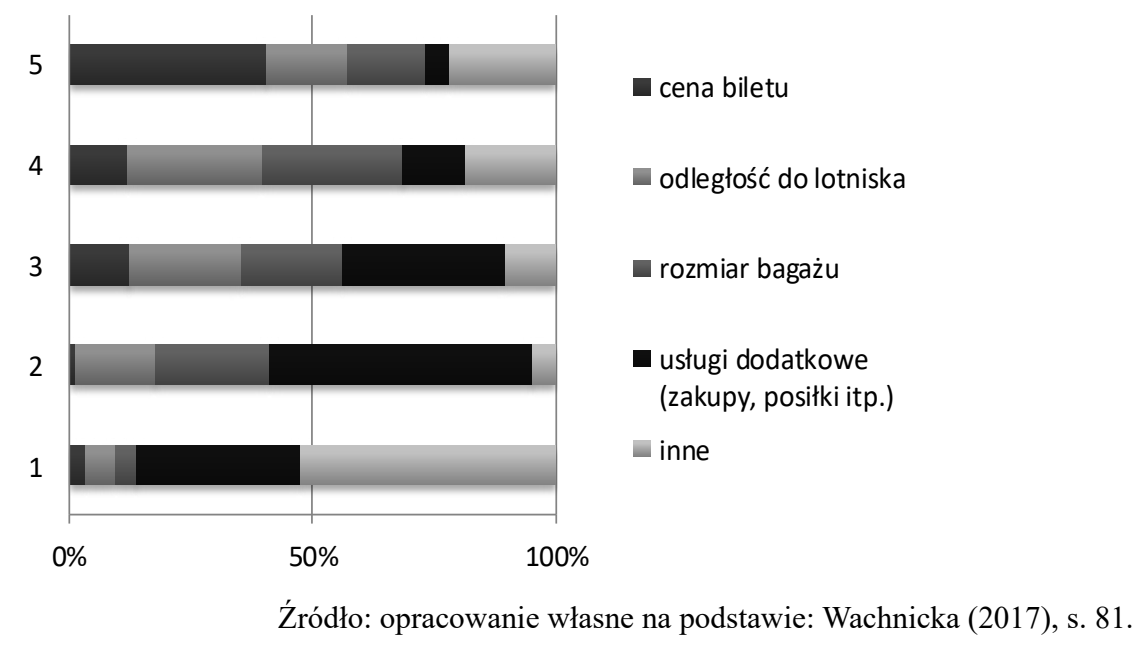

Pasażerowie pytani byli również o to, czy odległość od lotniska ma znaczenie przy wyborze danego połączenia. Prawie połowa odpowiedziała, że małe (46\%), a $33 \%$ bardzo małe. Duże znaczenie ma ten aspekt dla $12 \%$ ankietowanych, a tylko 9\% uznało ten czynnik za decydujący. Wskazuje to, że respondenci gotowi są pokonać większą odległość do portu lotniczego oferującego odpowiadające im atrakcyjne cenowo połączenie.

\section{Podsumowanie}

Rosnąca mobilność społeczeństwa, nowe technologie komunikacyjne, nieustanny rozwój oferty usługowej, nowo powstające podmioty gospodarcze, wreszcie decyzje lokalizacyjne samych mieszkańców powodują, że kierunki przepływów ludności 
cały czas podlegają istotnym przemianom. Porty lotnicze powinny być zlokalizowane w pobliżu szeroko rozumianej aglomeracji oraz zintegrowane z nią, by odgrywać jedną ze strategicznych ról w węźle transportowym jako ostatni lub pierwszy etap podróży. Wokół nich tworzy się także ruch stały, który generują pracownicy portu i instytucji funkcjonujących na terenie lotniska. Dostępność portu lotniczego jest szczególnie istotna dla wykorzystania jego potencjału, a tym samym generowania dodatkowych korzyści dla gospodarki regionu czy też miasta.

Przyjętą hipotezę badawczą zweryfikowano pozytywnie. Różne czynniki wpływają na preferencje pasażerów gdańskiego portu lotniczego. Czynnikiem decydującym o wyborze oferty jest cena oferty (69\% respondentów). Wśród innych determinant mających wpływ na ich decyzje znalazła się odległość od lotniska, którą za istotną uznało $27 \%$ badanych. Jednakże, co interesujące, tylko dla ok. $20 \%$ czynnik ten ma istotne bądź decydujące znaczenie. Najczęściej wskazywanym przez ankietowanych środkiem transportu dojazdu na lotnisko jest samochód osobowy (61\%). Należałoby te pilotażowe badania kontynuować, by móc wyciągnąć generalne wnioski. Powyższe wyniki wskazują jednak na potrzebę kształtowania bardziej zrównoważonej mobilności, by ograniczać presję na środowisko czy też kongestię wynikającą ze wzrostu liczby przemieszczeń.

\section{Literatura}

Banister, D. (2011). Cities, mobility and climate change, Journal of Transport Geography, 19. Bryx, M. (red.). (2014). Innowacje w zarzadzaniu miastami w Polsce. Warszawa: Oficyna Wydawnicza SGH.

Burnewicz, J. (2011). Spójny i innowacyjny system transportowy Pomorza. Gdańsk: Wydawnictwo Uniwersytetu Gdańskiego.

Chakuu, S., Kozlowski, P., Nędza, M. (2012). Podstawy transportu lotniczego. KrakówRzeszów-Zamość: WSIiZ.

Gadziński, J. (2013). Funkcjonowanie lokalnego systemu transportowego na tle wspótczesnych procesów urbanizacyjnych $w$ aglomeracji poznańskiej (praca doktorska). Poznań: UAM.

Graham, A. (2008). Managing Airports, An International Perspective. Oxford: Elsevier, Third edition.

Huderek-Glapska, S. (2011). Wplyw portu lotniczego na rozwój gospodarki regionu (praca doktorska). Poznań: Uniwersytet Ekonomiczny w Poznaniu. 
http://www.airport.gdansk.pl/airport/news/news_1877_4-miliony-pasazerow-2016-roku. html (5.05.2017).

Litman, T. (2006). Mobility as a Positional Good: Implications for Transport Policy and Planning, VTPI. Pobrano z: www.vtpi.org, www.vtpi.org/prestige.pdf (20.11.2017).

Rodrigue, J.-P., Comtois, C., Slack, B. (2006). The geography of transport systems. Nowy Jork: Routledge.

Ruciński, A., Madej, K. (2016). Polski rynek transportu lotniczego w perspektywie 2030 roku, 4 (7).

Szołtysek, J., Otręba, R. (2015). Wieloaspektowa analiza czynników kształtujących poczucie jakości życia w mieście - jako przesłanka tworzenia polityki logistycznej miasta. Prace Naukowe Uniwersytetu Ekonomicznego we Wrocławiu, 383.

Tłoczyński, D. (2016). Konkurencja na polskim rynku ustug transportu lotniczego. Gdańsk: Wydawnictwo Uniwersytetu Gdańskiego.

Wachnicka, M. (2017). Funkcjonowanie niskokosztowych przewoźników lotniczych na przykładzie Wizzair (praca magisterska). Gdynia: Akademia Morska w Gdyni.

\title{
CONTEMPORARY MOBILITY - GDAŃSK AIRPORT PASSENGERS PREFERENCES CASE STUDY
}

\begin{abstract}
Contemporary urban agglomerations as strong economic centers are usually the points where important transport routes, including air, meet. Passenger air transport is one of the fastest growing segments of the transport market. It is therefore reasonable to conduct research on passenger preferences to monitor their expectations. The aim of this paper is to present selected issues concerning contemporary mobility on the example of passengers' preferences in Gdansk airport. To achieve the purpose of the work the method of investigation of the incidental collection through an interview was used using a questionnaire survey. The hypothesis stating that the price is the most important for passengers, but other factors, such as distance from the airport, do also matter has been positively verified.
\end{abstract}

Keywords: mobility, passengers, Gdańsk airport

Translated by Adam Przybylowski

JEL code: $\mathrm{O} 43$ 